\title{
Design of Automatic Watering and Humidity Systems Based on Internet of Things for Screenhouse
}

\author{
$1^{\text {st }}$ Stefanus Marcellindo \\ Dept. Electrical Engineering \\ Universitas Sebelas Maret \\ Surakarta, Indonesia \\ stefanus.marcellindo@student.uns.ac.id \\ $4^{\text {th }}$ Savira Kharisma Putri \\ Dept. Agrotechnology \\ Universitas Sebelas Maret \\ Surakarta, Indonesia \\ savirakharisma@student.uns.ac.id
}

\author{
$2^{\text {nd }}$ Dina Mifika Sari \\ Dept. Electrical Engineering \\ Universitas Sebelas Maret \\ Surakarta, Indonesia \\ dinamifikas@student.uns.ac.id \\ $5^{\text {th }}$ Feri Adriyanto \\ Dept. Electrical Engineering \\ Universitas Sebelas Maret \\ Surakarta, Indonesia \\ feri.adriyanto@staff.uns.ac.id
}

\author{
$3^{\text {rd }}$ Muhammad Hammam Al-Choiri \\ Dept. Electrical Engineering \\ Universitas Sebelas Maret \\ Surakarta, Indonesia \\ hammamchoi23@student.uns.ac.id
}

\begin{abstract}
Central Bureau of Statistics reports that the population in Indonesia continues to increase every 10 years. The more the population swells, the greater the need for food. To meet the community's need for food availability, there are several agricultural obstacles such as growth criteria that are not by the type of commodity. Air temperature, humidity and intensity of water supply are included as criteria for plant growth (Budiman and Saraswati, 2005). Erratic weather changes make farmers unable to guarantee production results with good quality, and quantity. This research is designed using a tool that has been integrated with the Internet of Things system embedded in a raspberry pi as the overall processing core [1]. In addition to the raspberry pi, there are also several sensors as real condition readings, several relays as an electric pump controller and a solenoid valve as an electrical faucet controller, and these components will be connected with the ESP8266/NodeMcu module using a wifi connection. The data read by these sensors is displayed on the smartphone screen as a monitoring function in real-time and also the user can directly take action using the remote control, both automatic actions using machine learning or manual action. This sophisticated screenhouse can perform irrigation actions and temperature regulation automatically without having to do direct monitoring every time. The use of this system in agriculture allows the owner to not need to do direct monitoring by coming to the screenhouse, users can simply monitor using a smartphone connected to the Internet network. The application of this system can carry out watering actions and regulate the temperature in the screenhouse room automatically according to the aspects of good growth criteria for plants. Like controlling the microclimate in the screenhouse
\end{abstract}

Keywords-temperature, humidity, farmers, production, internet of things

\section{INTRODUCTION}

The increasing population in Indonesia causes an increase food needs. This has led to food diversification, which often uses vegetables and fruit as alternative food ingredients. However, there are several problems in the cultivation of vegetables and fruits on agricultural land, one of which is extreme weather changes.

The effect of extreme weather changes on vegetable and fruit crops is the mismatch of air temperature, air humidity, and soil moisture with plant needs. Each plant has different growing criteria to produce the most optimal harvest. For example, vegetables are better cultivated in the highlands because of the more suitable microclimate conditions. Therefore, a temperature and humidity control is needed so that land productivity is guaranteed.

\section{BACKGROUND}

\section{A. Previous studies}

In previous studies, an integrated irrigation system with NRF24L01 wireless communication was able to communicate well between modules only at a distance of 35 meters, where this distance could not reach wider agricultural land. Srishi Rawal (2017) also conducted research in agricultural systems by building an IoT-based irrigation using Arduino Uno as a base [2]. In addition, Yuthika et al (2017) also made a paper entitled "Intelligent IoT Based Automated Irrigation System". In this study, an IoT-based automatic watering was developed using the K-Nearest Neighbor method to classify soil conditions into four categories, namely wet, slightly wet, dry, slightly dry based on soil moisture and temperature parameters [3]. Then Pavankumar Naik et al (2018) also conducted research on IoT-based automatic watering using Arduino Yun as the brain [4]. Abraham Sudharson Ponraj (2019) also researched machine-learning approaches for IoT in agriculture so that several categories of machine learning comparisons were produced, one of which was land management [5]. A. Neelima (2018) also conducted research on IoT irrigation systems based on soil moisture sensors and Arduino which are connected to the internet using a wifi module whose data is sent to Thingspeak [6]. However, several studies that have been conducted have only focused on watering and sensor readings of growth criteria. Whereas the treatment of plant growth criteria is important, especially the microclimate.

\section{B. Air Temperature and Humidity}

A good air temperature for plants must be in accordance with the needs of each plant phase, such as the germination phase, flowering phase, and ripening phase [7]. Air humidity is the amount or content of water vapor in the air that comes from evaporation of ground water and plants [8]. Each vegetable or fruit commodity also has different requirements for air temperature and humidity. For example, strawberries are suitable for relatively cold temperatures, which are around 22-280C, while the humidity needed for strawberries is $80-90 \%$ [9]. Higher temperature will increase the process of photosynthesis and respiration. However, plant areas with temperature above optimum limit result more respiration than photosynthesis, so that plant production decreases [10]. 


\section{Soil Temperature and Humidity}

Soil temperature is a soil characteristic that affects plant growth, humidity, microbial activity, and soil structure. Microbial activity functions to decompose organic compounds into nutrients. Soil moisture is the amount of water content in the soil pores. The existence of this water is dynamic because there is percolation and evaporation. The process of plant root growth and soil microbial life is related to soil moisture conditions. Soil moisture levels play a role in water resource management and irrigation. Each vegetable or fruit commodity also has different needs for soil temperature and soil moisture. For example, cabbage requires a soil temperature of $290^{\circ} \mathrm{C}$ and a soil moisture of $60 \%$ ASM (American Standard Method) [11].

\section{TECHNICAL APPROACH}

A. Schematic and Design

With the main components consisting of
a) Raspberry
b) Camera
c) LED oled
d) Microcontroller ESP8266
e) BME 280
f) YL-69
g) DS18B20
h) LDR
i) Relay
j) Solenoid Valve
k) Water pump

All of these components hooked up as shown in.

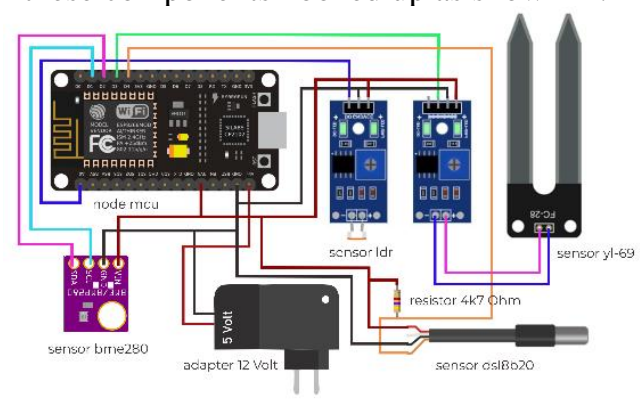

Fig 1. Screen house data reading wiring diagram

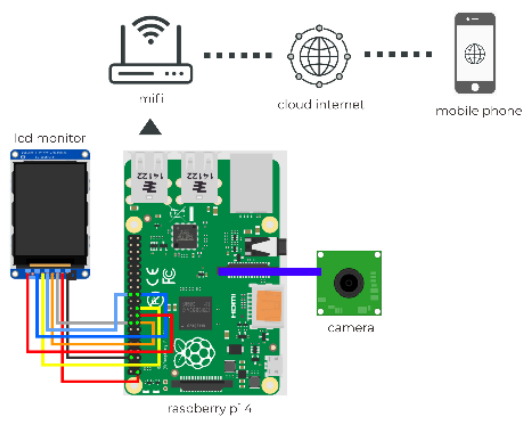

Fig 2. Raspberry Pi wiring diagram

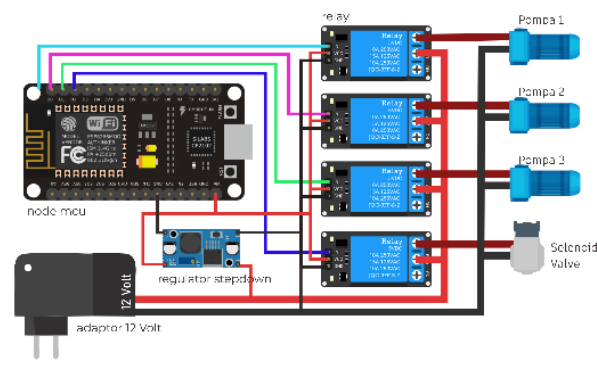

Fig 3. Relay controller circuit and solenoid valve wiring diagram

This screenhouse is designed with a size of $1000 \mathrm{~m}^{2}$ which can accommodate 1620 plants, and 3D designs are made using the blender application, with results like this:

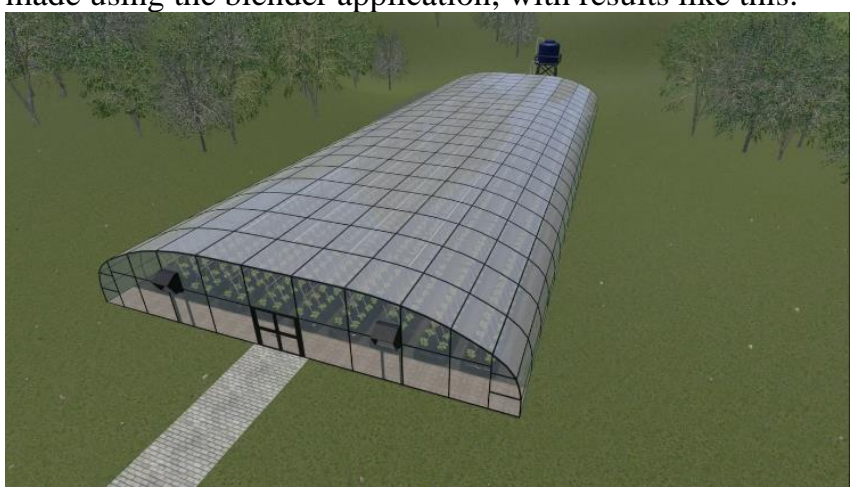

Fig 4. Sreenhouse top view

B. Watering and humidity system

In this watering and humidit system, there thre stage, namely:

- First Stage: Data retrieval using temperature and humidity sensors

- Second Stage: After the first stage of watering and humidity system, data is processed using machine learning

- Third Stage: When the result of data processing is less, the system will operate for a long time. But, when the result of data processing are sufficient, the system will operate in a short time.

\section{Monitoring System}

The monitoring system uses a raspberry pi as server and connected to mifi, so it can be accessed by the global Internet and smartphone through the internet of things. Besides that, raspberry pi connected to an oled LCD so that data can be observed directly in the screenhouse.
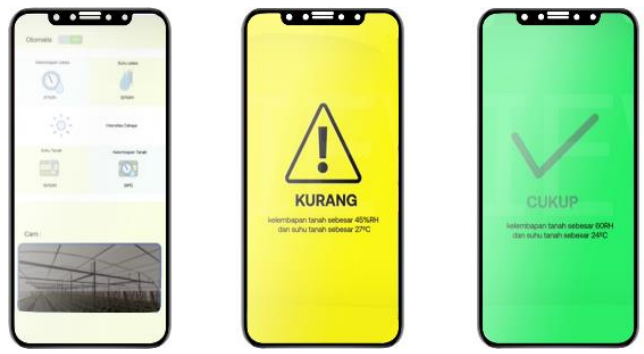

Fig 5. Monitoring Display Interface 


\section{Calculation}

Use this equation to find inlet losses and turning losses by 90 degrees

$h i=\left(\frac{1}{C c}-1\right)^{2} \frac{V 1^{2}}{2 g}$

$h b i=\sin ^{2} x \frac{V 1^{2}}{2 g}$

Use this equation to find friction loss

$h i=\frac{f L 1}{D 1} \frac{V 1^{2}}{2 g}$...

H=hi1+hbi+hi2+hi3+hi4+hi5+hc1+hi6+hc2+hi7+hi8+hi 9

$\mathrm{H}=0,025 V 1^{2}+0,05 V 1^{2}+0,2259 V 1^{2}+0,025 V 1^{2}$ $+0,00018 V 1^{2}+0,237 V 1^{2}+0,002 V 1^{2}+1,1385 V 1^{2} 0,813 V 1$ $+21,0492 V 1^{2}+0,1 V 1^{2}+1,1694 V 1^{2}$ $=24,83 V 1^{2}$

$\mathrm{H}=$ Water Level + Reservoir Height

$6=24,83 V 1^{2}$

$V 1^{2}=\frac{24,83}{6}=0.241$

$V 1=0,491 \mathrm{~m} / \mathrm{s}$

The total cross-sectional area of the watering hole

$\mathrm{D}=5 \mathrm{~mm}=0,005 \mathrm{~m}$

$A=\frac{\pi x D^{2}}{4}$

$$
=\frac{\pi x(0,002)^{2}}{4}=0.00000314 m^{2}
$$

Watering hole total discharge

$Q=A x V$

$Q=1,54 c c / s$

The total length of the water flow path

$S=4,5 m+1,5 m+0,5 m+0,5 m+6 m+2 m+47 m$ $=62 \mathrm{~m}$

So, the time it takes for the water to reach the end of the pipe is

$t=\frac{S}{V}$

$t=\frac{62}{0,491}=126.27$ second soil moisture required when conditions are dry $(30 \%)$

$$
70 \%-20 \%=50 \%
$$

Meanwhile, to increase soil moisture by $5 \%-7 \%$ requires $200 \mathrm{cc}$ of water, so the water needed is:

$V=200 \times 8=1600 c c$

$t=\frac{V}{Q}=\frac{1600}{1.54}=1040$ second

So, the total time required is:

$t$ total $=126.27+1040=1166,27$ second $=20$ minutes

soil moisture required when conditions are slightly dry

$$
70 \%-40 \%=30 \%
$$

Meanwhile, to increase soil moisture by $5 \%-7 \%$ requires $200 \mathrm{cc}$ of water, so the water needed is:

$V=200 \times 6=1200 c c$

$t=\frac{V}{Q}=\frac{1200}{1.54}=780$ second

So, the total time required is:

$t$ total $=126.27+780=806,27$ second

soil moisture required when conditions are slightly wet

$$
70 \%-55 \%=15 \%
$$

Meanwhile, to increase soil moisture by $5 \%-7 \%$ requires $200 \mathrm{cc}$ of water, so the water needed is:

$V=200 \times 2=400 c c$

$t=\frac{V}{Q} \ldots(7)$

$t=\frac{400}{1.54}=260$ second

So the total time required is

$t$ total $=126.27+260=386,27$ second $=7$ minutes

Required soil moisture when wet

$$
70 \%-65 \%=15 \%
$$

Meanwhile, to increase soil moisture by 5\% - 7\% requires $200 \mathrm{cc}$ of water, so the water needed is:

$V=200 \times 1=200 c c$

$t=\frac{V}{Q}=\frac{400}{1.54}=130$ second 


$$
m=428,57 \mathrm{~kg}
$$

Speed on pipe:

$$
\begin{aligned}
\mathrm{D} & =1 \text { inch }=0,0254 \mathrm{~m} \\
A & =\frac{\pi x D^{2}}{4} \\
& =\frac{\pi x(0,0254)^{2}}{4}=0.000506911 \mathrm{~m}^{2} \\
\mathrm{Q} & =12 \mathrm{~L} / \mathrm{min}=0,2 \mathrm{~L} / \mathrm{s}=0,0002 \mathrm{~m}^{2} \\
V & =\frac{Q}{A} \\
V & =\frac{0,0002}{0,000506}=0,4 \mathrm{~m} / \mathrm{s}
\end{aligned}
$$

Discharge at nozzle hole

$$
\begin{aligned}
& \text { Anozzle }=\frac{\pi x D^{2}}{4} \\
& =\frac{\pi x(0,0001)^{2}}{4}=0.0000000078 \mathrm{~m}^{2}
\end{aligned}
$$

$$
\mathrm{A} 1 \mathrm{~V} 1=\mathrm{A} 2 \mathrm{~V} 2 \ldots(8)
$$

$$
0,000506911 \times 0,4=0,0000000078 \times \mathrm{V} 2
$$

$\mathrm{V} 2=286 \mathrm{~m} / \mathrm{s}$

$Q=V A$

$Q=286 \times 0,0000000078=0,000002 \mathrm{~m}^{3} / \mathrm{s}$

There are 90 nozzle holes, so

$Q=0,00000225 \times 90=0,00020 \mathrm{~m}^{3} / \mathrm{s}$

With a density of water vapor $750 \mathrm{~kg} / \mathrm{m}^{3}$ then

Total water particles per second $=$ $0,00020 \times 750=0,15 \mathrm{~kg} / \mathrm{s}$

$$
m c \Delta t 1=m c \Delta t 2 \ldots(9)
$$

$$
\begin{gathered}
m .4200 .(18-6)=3600.1000 .(30-18) \\
m .4200=3600.1000 \\
m=857,142 \mathrm{~kg}
\end{gathered}
$$

So, it takes time to lower the temperature from $30^{\circ} \mathrm{C}$ to $18^{\circ} \mathrm{C}$

$t=0,15 \times 857,142=5714$ seconds $=1$ hour 35 minutes

To lower the temperature from $24^{\circ} \mathrm{C}$ to $18^{\circ} \mathrm{C}$ then

$$
\begin{gathered}
m c \Delta t 1=m c \Delta t 2 \\
m .4200 \cdot(18-6)=3600 \cdot 1000 \cdot(24-18)
\end{gathered}
$$

So, it takes time to lower the temperature from $24^{\circ} \mathrm{C}$ to $18^{\circ} \mathrm{C}$

$t=0,15 \times 428,57=2857$ seconds $=47$ minutes.

\section{SYSTEM FUNCTION}

A. Architecture of System

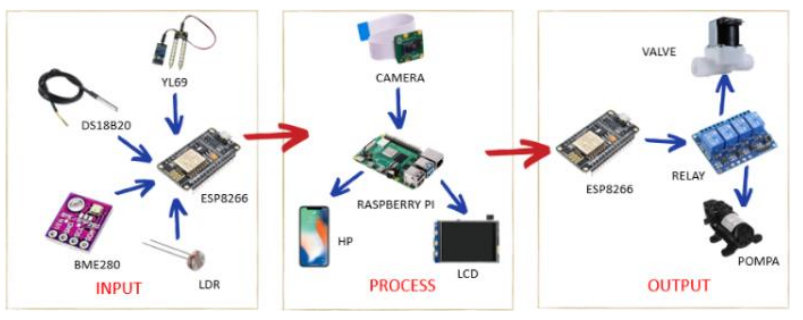

Fig 6. Component workflow

(1) IoT (Internet of Things)

The monitoring system is an activity that occurs in a high-level area, which is carried out so that measurements can be made through time, which shows the movement towards a goal or away from that goal. The purpose of monitoring itself is so that activities are controlled according to plan and in accordance with proper procedures. The monitoring system will provide information about the status and the tendency that measurements and evaluations are repeated over time, if something is not desired, the results will be directly generated by the monitoring system without interrupting the process. IoT is a concept that has the ability to transfer data objects over a network without requiring human-to-human or human-to-computer interaction. IoT has evolved from the convergence of wireless technologies, micro-electromechanical systems (MEMS), and the Internet [13].

(2) Component of The System

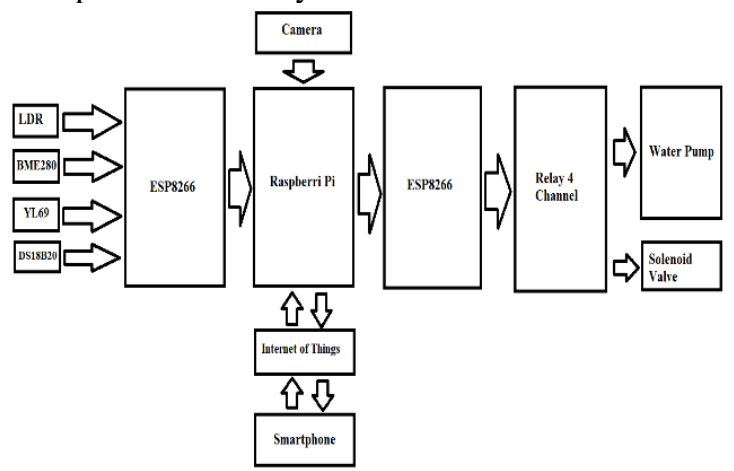

Fig 7. Block Diagram

The system is divided into 3 subsystems, namely input subsystem, process subsystem, and output subsystem. The input subsystem consists of several sensors and an ESP8266 microcontroller to detect plant growth criteria. LDR sensor is used to detect light intensity, BME280 sensor is used to detect air temperature and humidity, YL69 sensor is used to detect soil moisture, ds18b20 sensor is used to detect soil temperature.The process subsystem 
section consists of a raspberry pi and a server to process data from the input subsystem. In addition, this section is equipped with a camera module to monitor in real time. Then the last is the output subsystem where there is an ESP8266 microcontroller, 4 channel relay, water pump, and solenoid valve to carry out commands from the process subsystem

\section{B. Implementations of Systems}

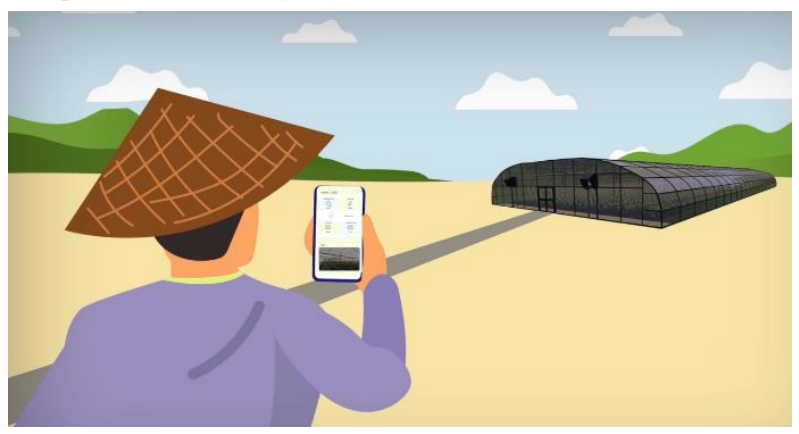

Fig 8. Implementations of Systems

1) Watering and humidity systems

This device work, in a few step:

a) sensors detect plant growth criteria

b) The sensor reading data is then processed by the microcontroller ESP8266

c) Then the data is sent to the raspberry pi via wireless communication

d) data processing is carried out using machine learning with the following steps:

- Calculate the value of the distance euclidian distance

- Then sort the calculation results

- The last one is to determine the most classification

e) The classification result data is then sent to the microcontroller ESP8266 which is connected to a relay to control the solenoid valve and water pump

f) when the classification results show that the soil temperature and soil moisture are still lacking, the microcontroller will instruct the relay connected to the solenoid valve to do watering for a long time

g) when the classification results show that the air temperature and humidity are still lacking, the microcontroller will instruct the relay connected to the water pump to condense for a long time

h) when the classification results show that the temperature and humidity are sufficient, the microcontroller will instruct the relay to operate at several time

2) Monitoring System Device
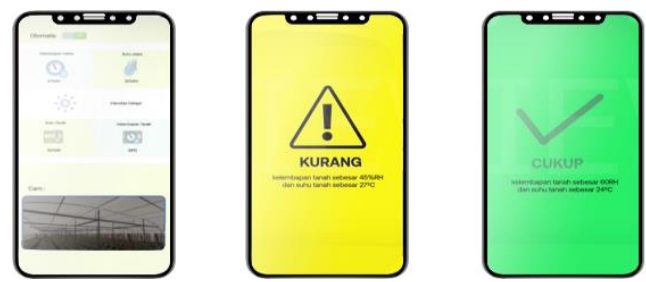

Fig 9. Monitoring Display Interface
In this screenhouse monitoring application, some data is presented from the readings of existing sensors, such as readings from air humidity sensors, air temperature sensors, soil moisture sensors, soil temperature sensors, and light intensity sensors. In addition to monitoring the results of sensor readings in real-time, in this application there are monitoring results from a camera on the raspberry pi which can also be monitored in real-time.

This device, works in few steps:

a. At one time if the data presented in the monitoring application does not match the normal condition data, the system will send a warning to the raspberry pi in the screenhouse.

b. After the raspberry pi receives a warning from the user application, the system automatically performs a series of commands to run the irrigation system and the condensation system for a certain time until it reaches the appropriate temperature and humidity.

\section{CONCLUSION}

In this paper, we offer an innovative improvement that is applied to the agricultural sector, which also supports the 4.0 technology era where in its operation a sophisticated system that is integrated between hardware and Internet networks is applied. This sophisticated screenhouse can perform irrigation actions and temperature regulation automatically without having to do direct monitoring every time. The use of this Screenhouse is proposed to be a product that supports the digital era because:

1. The use of this system in agriculture allows the owner to not need to do direct monitoring by coming to the screenhouse, users can simply monitor using a smartphone connected to the Internet network.

2. The application of this system can carry out watering actions and regulate the temperature in the screenhouse room automatically according to the aspects of good growth criteria for plants. Like controlling the microclimate in the screenhouse.

3. This screenhouse system has implemented machinelearning technology so that the actions taken will be more accurate and efficient.

4. With the presence of a router in this screenhouse system and the use of local servers, this system can run with or without global Internet, so Internet signal limitations are not an obstacle for this system.

\section{ACKNOWLEDGMENT}

The author would like to thank the Ministry of Education, Culture, Research, and Technology who has provided PKM funds. The author also to thank you to the UNS academic community who have supported and provided many suggestions to the author.

\section{REFERENCES}

[1] Lutfiyana L, Hudallah N, Suryanto A. 2017. Rancang bangun alat ukur suhu tanah, kelembaban tanah, dan resistansi. Jurnal Teknik Elektro 9(2) : 80-86..

[2] Rawal, S. 2013. IoT based Smart Irrigation System. International Journal of Computer Application. 159 (8):7-11. 
[3] Shekhar, Y., Dagur, E., \& Mishra, S. (2017), Intelligent IoT Based Automated Irrigation System. International Journal of Applied Enineering Research. 12 (18):7306-7320.

[4] Naik, P., Kumbi, A., Katti, K., \& Telkas, N. (2018). AUTOMATION OF IRRIGATION SYSTEM USING IOT. International Journal of Engineering and Manufacturing Science. 8 (1):77-88.

[5] Nishom, M. (2019). Perbandingan Akurasi Euclidean Distance, Minkowski Distance, dan Manhattan Distance pada Aloritma KMeans Clustering berbasis Chi-Square. Jurnal Informatika: Jurnal Pengembangan IT (JPIT), 4 (1):20-24.

[6] A. Neelima, Sravanthi, M. S., M.L. Ramyasri, \& K. Yuvasri. (2018). Sensor Based Automated Moisture Monitoring Irriation System with IoT. Internatio Journnal of Innovation Research in Computer and Communication Engineering. 6 (1): 115-121.

[7] Taufiq A, Sundari T. 2012. Respons tanaman kedelai terhadap lingkungan tumbuh. Buletin Palawija 23: 13-26.

[8] Friadi R, Junadhi J. 2019. Sistem kontrol intensitas cahaya, suhu dan kelembaban udara pada greenhouse berbasis raspberry pi. Journal of Technopreneurship and Information System 2(1): 30-37.

[9] Budiman S, Saraswati D. 2005. Berkebun stroberi sceara komersial. Jakarta: Seri Agribisnis.

[10] Gustia H. 2014. Pengaruh penambahan sekam bakar pada media tanam terhadap pertumbuhan dan produksi tanaman sawi (Brassica juncea L.). Jurnal Widya Kesehatan dan Lingkungan 1(1): 12-17.
[11] Lutfiyana L, Hudallah N, Suryanto A. 2017. Rancang bangun alat ukur suhu tanah, kelembaban tanah, dan resistansi. Jurnal Teknik Elektro 9(2) : 80-86.

[12] Adaptasi Rancangan Rumah Tanaman Untuk Iklim Tropika Basah. http://repository.ipb.ac.id/ BAB2_Adaptasi\%20Rancangan.

[13] Yudhanto, Yudha.2015. Apa itu IoT (Internet of Thing). Surakarta

[14] Donald J. 2019. Machine Learning with the Raspberry Pi. *Apress, Berkeley, CA *: 1-44.

[15] Apa itu modul esp 8266. https://www.nyebarilmu.com/apa-itu-modulesp8266/.

[16] Humidity sensor measuring relative humidity, barometric pressure and ambient temperature. https://www.boschsensortec.com/products/environmental-sensors/humidity-sensorsbme280/.

[17] Lestari Sri. 2018. Pembuatan Alat Ukur Kelembaban Tanah Menggunakan Sensor Soil Moisture YL-69 Berbasis Atmega-32. Universitas Sumatera.

[18] DS18B20 Temperature Sistem. https://www.elprocus.com/ds18b20temperature-sensor/.

[19] What is Light Dependent Resistor : Circuit \& Its Working. https://www.elprocus.com/ldr-light-dependent-resistor-circuit-andworking/.

[20] Relay. https://circuitglobe.com/relay.html. 